\title{
Pathogenesis of Bronchopulmonary Dysplasia
}

\author{
Don Hayes, Jr. ${ }^{\text {b, c }}$ David J. Feola ${ }^{a}$ Brian S. Murphy ${ }^{c}$ Lori A. Shook ${ }^{b}$ \\ Hubert O. Ballard ${ }^{b}$ \\ ${ }^{a}$ Department of Pharmacy Practice and Science, University of Kentucky College of Pharmacy, and Departments of \\ ${ }^{b}$ Pediatrics and ${ }^{C}$ Internal Medicine, University of Kentucky College of Medicine, Lexington, Ky., USA
}

\section{Key Words}

Bronchopulmonary dysplasia $\cdot$ Chronic lung disease of infancy · Pathogenesis · Pathophysiology

\begin{abstract}
Bronchopulmonary dysplasia (BPD) refers to a heterogeneous group of lung disorders in infants that is commonly associated with prematurity and surfactant deficiency. BPD results from the complex interplay between impairments in the premature lung such as surfactant deficiency, perinatal insults such as infection, and damage resulting from supportive care of the infant due to barotrauma or volutrauma from mechanical ventilation and oxygen toxicity from supplemental oxygen administration. These factors result in chronic inflammation in the infant lung with recurring cycles of lung damage and repair that may impair alveolarization and vascularization in the developing lungs. As our insight in how to treat BPD improves along with the ability to do so with developing technology and therapies, the underlying pathogenesis will also change. The term 'new' BPD is now commonly used, to describe the changes seen in the post-surfactant era. This discussion reviews the pathogenesis of BPD according to the current medical literature.
\end{abstract}

Copyright $\odot 2009$ S. Karger AG, Base

\section{Introduction}

Bronchopulmonary dysplasia (BPD) is the product of a heterogeneous group of lung disorders that begin in the neonatal period. The inciting factor of BPD is often prematurity with respiratory distress syndrome (RDS) from surfactant deficiency. Supportive care with mechanical ventilation leads to barotrauma, volutrauma, and oxygen toxicity. All of these factors contribute to the chronic pulmonary abnormalities that follow, including persistent structural changes that result in significant effects on lung mechanics, gas exchange, and pulmonary vasculature. The definition of BPD has continued to evolve since Northway et al. [1] reported lung damage as a result of prolonged mechanical ventilation in premature infants with severe RDS. In 1969, Pusey et al. [2] described diffuse interstitial fibroplasia associated with mechanical ventilation in newborns including patients without RDS. There was no clear relationship demonstrated between the use of high oxygen concentration and BPD, thus suggesting barotrauma as the primary cause [2]. Further definitions of clinical BPD have included supplemental oxygen requirement at 28 days postnatal age $[3,4]$ and 36 weeks postmenstrual age (PMA) $[5,6]$. The National Institutes of Child Health and Human Development (NICHD) workshop established diagnostic criteria for BPD that included gestational age and disease severity (table 1) [7]. Ehrenkranz et al. [8] validated the accuracy of the consensus

Don Hayes, Jr., MD

Departments of Pediatrics and Internal Medicine

University of Kentucky College of Medicine, J410 Kentucky Clinic

740 South Limestone Street, Lexington, KY 40536 (USA)

Tel. +1 859257 5536, Fax +1 859257 1888, E-Mail don.hayes@uky.edu 
Table 1. Diagnostic criteria for BPD

\begin{tabular}{|c|c|c|}
\hline & $<32$ weeks GA & $\geq 32$ weeks GA \\
\hline \multirow[t]{2}{*}{ Time point of assessment } & $\begin{array}{l}36 \text { weeks PMA or discharge home, } \\
\text { whichever comes first }\end{array}$ & $\begin{array}{l}>28 \text { days but }<56 \text { days postnatal age or discharge } \\
\text { home, whichever comes first }\end{array}$ \\
\hline & \multicolumn{2}{|c|}{ Treatment with oxygen $>21$ for at least 28 days plus } \\
\hline Mild BPD & $\begin{array}{l}\text { breathing room air at } 36 \text { weeks PMA or } \\
\text { discharge, whichever comes first }\end{array}$ & $\begin{array}{l}\text { breathing room air by } 56 \text { days postnatal age or } \\
\text { discharge, whichever comes first }\end{array}$ \\
\hline Moderate BPD & $\begin{array}{l}\text { need }^{1} \text { for }<30 \% \text { oxygen at } 36 \text { weeks PMA } \\
\text { or discharge, whichever comes first }\end{array}$ & $\begin{array}{l}\text { need }{ }^{1} \text { for }<30 \% \text { oxygen at } 56 \text { days postnatal age or } \\
\text { discharge, whichever comes first }\end{array}$ \\
\hline Severe BPD & $\begin{array}{l}\text { need }{ }^{1} \text { for } \geq 30 \% \text { oxygen and/or positive pressure } \\
\text { (PPV or NCPAP) at } 36 \text { weeks PMA or discharge, } \\
\text { whichever comes first }\end{array}$ & $\begin{array}{l}\text { need }{ }^{1} \text { for } \geq 30 \% \text { oxygen and/or positive pressure } \\
\text { (PPV or NCPAP) at } 56 \text { days postnatal age or dis- } \\
\text { charge, whichever comes first }\end{array}$ \\
\hline
\end{tabular}

$\mathrm{GA}=$ Gestational age; NCPAP $=$ nasal continuous positive air way pressure; $\mathrm{PPV}=$ positive-pressure ventilation. The diagnostic criteria were reprinted with permission from Jobe and Bancalari [7] (Copyright ${ }^{\odot}$ 2001, American Thoracic Society).

${ }^{1}$ A physiologic test confirming that the oxygen requirement at the assessment time point remains to be defined. This assessment may include a pulse oximetry saturation range. BPD usually develops in neonates being treated with oxygen and PPV for respiratory failure, most commonly RDS. Persistence of clinical features of respiratory disease (tachypnea, retractions, or rales) are considered common to the broad description of BPD and have not been included in the diagnostic criteria describing the sever- ity of BPD. Infants treated with oxygen $>21 \%$ and/or positive pressure for nonrespiratory disease (e.g. central apnea or diaphragmatic paralysis) do not have BPD unless they also develop parenchymal lung disease and exhibit clinical features of respiratory distress. A day of treatment with oxygen $>21 \%$ means that the infant received oxygen $>21 \%$ for $>12$ h on that day. Treatment with oxygen $>21 \%$ and/or positive pressure at 36 weeks PMA, or at 56 days postnatal age or discharge, should not reflect an 'acute' event, but should rather reflect the infant's usual daily therapy for several days preceding and following 36 weeks PMA, 56 days postnatal age, or discharge.
Table 2. Evolution of pathology in $\mathrm{BPD}^{1}$

\section{Old BPD}

Alternating areas of atelectasis and hyperinflation

Severe airway epithelial lesions

(hyperplasia and squamous metaplasia)

Decreased internal surface area and alveoli

Airway smooth muscle hyperplasia

Extensive fibroproliferation

Prominent vascular hypertensive lesions

\section{New BPD}

Decreased, large and simplified alveoli

(alveolar hypoplasia, decreased acinar complexity)

Negligible airway epithelial lesions

Variable airway smooth muscle hyperplasia

Variable interstitial fibroproliferation

Decreased, dysmorphic capillaries

Less severe arterial/arteriolar vascular lesions

Less septal fibrosis that appears more diffuse

\footnotetext{
${ }^{1}$ Modified and reprinted from Coalson [11], with permission from Elsevier.
}

definition of BPD in early infancy compared to other definitions.

In 1996, Cherukupalli et al. [9] detailed the pathologic findings of 48 infants dying from BPD or hyaline membrane disease, which were classified histologically into four groups: acute lung injury, proliferative phase, early repair phase, and late repair phase. In the post-surfactant era, there has been an evolutionary histological change in new BPD, as reported by Husain et al. [10], where there are fewer and larger simplified alveoli, negligible airway lesions, variable airway smooth muscle hyperplasia, variable interstitial fibroproliferation, fewer and dysmorphic capillaries, and less severe arterial lesions. The distal lung acinus having large alveoli with reduced decreased secondary crest formation is a primary finding in new BPD [10]. Findings of decreased alveolarization and diminished and dysmorphic platelet endothelial cell adhesion molecule (an endothelial cell marker) staining are consistent with an arrest at the canalicular phase of lung development [10]. Table 2 outlines the evolution of the pathology of 'old' versus 'new' BPD. Coalson [11] published an excellent review on lung pathology observed in new BPD in 2003. 


\section{Lung Growth and Development}

The fetal airways are well formed by 20 weeks of gestation, with alveoli appearing only after about 32 weeks of gestation; term infants have approximately $30 \%$ of the adult number of alveoli [11-14]. At the threshold of viability between 23 and 24 weeks of gestation, the canalicular phase of lung development transitions to the saccular stage [14]. Vascular growth is closely linked to the alveolarization process, thus inhibition of vascular growth directly impairs alveolarization [15]. Abman [16] described the concept of a 'vascular hypothesis' in the development of BPD. During the initial 17 weeks of gestation, the airways are a template for pulmonary blood vessel development in that the vessels form by vasculogenesis around the branching airways [17]. In the canalicular phase, capillaries form by angiogenesis with cell division occurring in existing capillaries rather than in the general mesenchyme [18]. Vascular endothelial growth factor (VEGF), which is involved in angiogenesis and vasculogenesis, was found to have impaired signaling and thus thought to play a role in the development of BPD in a preterm baboon model [19] as well as in human infants [20, 21]. Recent evidence demonstrated that intratracheal VEGF gene transfer promoted alveolarization in a hyperoxiainduced BPD model of newborn rat pups [22], and that increased expression of VEGF enhances maturity in the developing lung [23], indicating that VEGF, or possibly even other angiogenic agents, may have therapeutic implications. However, VEGF can have injurious as well as potentially beneficial developmental effects, of which some are nitric oxide (NO) dependent with others being NO independent, so selective manipulation of any VEGFbased intervention using NO inhibitors are likely needed for maximal potential clinical benefit [23].

\section{Postnatal Factors in BPD}

\section{Oxygen Toxicity, Antioxidants, and Nutrition}

$\mathrm{BPD}$ is a complex disorder with multiple factors contributing to the onset and progression of the disease. Prolonged periods of high oxygen concentrations lead to biochemical and histological effects on lung tissue [24]. Oxygen toxicity was originally attributed to be the cause of BPD and continues to be a major factor today. Oxygen toxicity is mediated through reactive oxygen species, thus antioxidant therapy has been considered as a potential preventive or treatment option for BPD [25-27]. The human neonate has antioxidant defenses including gluta- thione peroxidase and catalase that may be low compared to an adult and even lower in the fetus [28]. Antioxidant enzymes continue to be studied in neonates. A recent report indicated that erythrocyte cellular glutathione peroxidase may play an important role in the development of BPD, with lower levels of activity present in early postnatal life being a potential risk factor for BPD [29]. Due to antioxidant deficiencies in preterm infants, numerous studies have been performed to assess the potential benefits of antioxidant therapy. Preterm infants are known to be deficient in $\mathrm{N}$-acetyl cysteine (NAC), a precursor of cysteine, which is the rate-limiting precursor for glutathione synthesis [30]. There is evidence that a further decrease in NAC occurs with the onset of BPD [31]. Ahola et al. [32] demonstrated that NAC supplementation in a randomized multicenter, double-blind trial in infants with extremely low birth weight $(\mathrm{n}=391$, weight 500 $999 \mathrm{~g}$ ) did not affect the incidence of death or BPD (51\% in the NAC group versus $49 \%$ in the control group) or the severity of BPD.

Vitamin A and its metabolites, which are needed for normal lung growth and ongoing integrity of respiratory tract epithelial cells, are low in premature infants [33]. Research in animals has revealed that vitamin A supplementation reduces both hyperoxia-induced lung injury in newborn rats [34] and impaired alveolarization and abnormal lung elastin in preterm lambs with chronic lung injury [35]. Furthermore, randomized, controlled trials have demonstrated that vitamin A supplementation in very low birth weight infants is associated with a reduction in death or oxygen requirement at 1 month of age and oxygen requirement among survivors at 36 weeks PMA, with the latter outcome being limited to infants with birth weight $<1,000 \mathrm{~g}$ [36]. In a multicenter randomized trial, intramuscular vitamin A supplementation $(5,000$ IU three times per week for 4 weeks) given to extremely low birth weight infants, requiring respiratory support at $24 \mathrm{~h}$ of age, reduced the rate of death or BPD at 36 weeks PMA from 62 to 55\% [37].

Other antioxidant therapies have been investigated, including a human study that demonstrated that vitamin E supplementation did not offer any protection for the development of BPD in infants with a birth weight $<1,500 \mathrm{~g}$ [38]. Intratracheal administration of copperzinc-superoxide dismutase on ventilated premature infants did not reduce the incidence of death or BPD but did demonstrate the need for fewer medications for wheezing in the 1st year of life [39].

Exposure to positive pressure ventilation and hyperoxia is complicated by an immature or deficient pulmo- 
nary antioxidant defense system in the neonate, which leads to detrimental effects on the ability of premature lungs to resist and repair ongoing injury [40]. Varsila et al. [41] demonstrated that immaturity was the most important factor explaining free radical-mediated pulmonary protein oxidation in newborn infants, and oxidation of proteins is related to the development of chronic lung disease. Those patients who developed BPD showed significantly higher protein oxidation, quantified as protein carbonylation in tracheal aspirates on days 1-6 of life [41]. Varsila et al. [42] also reported that during the postnatal period, immaturity was a major factor determining the rate of free radical-mediated lipid peroxidation with expired ethane and pentane levels being much higher during the first 7 days of life in preterm compared to term infants.

Malondialdehyde, a product of lipid peroxidation, is a sensitive marker of oxidative damage in tissues [43]. Collard et al. [43] showed a significant correlation between bronchoalveolar lavage (BAL) concentration of malondialdehyde and the development of BPD in 43 ventilated infants $<32$ weeks of gestation, but no correlation between malondialdehyde concentration and preceding oxygen exposure. A strong correlation existed between BAL malondialdehyde concentration and presence of endotracheal infection [43]. Despite its potential to cause damage, the actual contribution of supplemental oxygen to oxidative damage in the premature lung still remains unclear.

\section{Mechanical Ventilation}

In 1976, Taghizadeh and Reynolds [44] suggested the most important factor in the pathogenesis of BPD was mechanical trauma to the lung from the use of excessively high peak airway pressures during mechanical ventilation. Residual symptoms in the first years of life correlated with duration of ventilation and secondary infection in survivors of hyaline membrane disease during infancy [45]. Studies in preterm lambs demonstrated that prolonged mechanical ventilation disrupted lung development and produced pulmonary histopathologic changes that were very similar to those seen in the lungs of preterm infants who die with BPD [46]. In chronically ventilated preterm lambs, pulmonary histopathology was characterized by nonuniform inflation patterns, impaired alveolar formation, abnormal abundance of elastin, increased muscularization of terminal bronchioles, as well as inflammation and edema [46]. Less atelectasis, less alveolar formation, and more elastin was seen with slow, deep ventilation as compared to rapid, shallow ven- tilation [46]. In these preterm lambs, chronic lung disease was not prevented by surfactant replacement at birth, did not require arterial hyperoxia, and is affected by tidal volumes [46].

Garland et al. [47] discovered that ventilatory management before artificial surfactant rescue treatment that resulted in hypocarbia increased the risk of BPD, with an inverse relationship between hypocarbia and BPD. These findings suggested that early ventilatory management should not only provide adequate oxygenation but also limit hyperventilation [47]. With an innovative study, Björklund et al. [48] obtained diagrams relating airway pressure to expired volume in 11 paralyzed neonates having them exhale passively through a flowmeter, starting at 30 and ending at $0 \mathrm{~cm} \mathrm{H}_{2} 0$ of pressure, before and approximately $30 \mathrm{~min}$ after surfactant therapy. The total lung capacity increased by $10 \%$ or more in 5 infants, but it remained unchanged in the others [48]. Pressure-volume curves became markedly steeper at low pressures after surfactant in most infants and dynamic compliance was unchanged, whereas specific dynamic compliance decreased with no significant immediate change in ventilation homogeneity measured as pulmonary clearance delay [48]. The investigators concluded that during the first $30 \mathrm{~min}$, surfactant acted mainly by stabilizing already ventilated air spaces [48]. Bland et al. [49] found in a mouse model that increased elastin synthesis, coupled with increased elastase activity and reduced abundance of proteins in the lung that regulates elastic fiber assembly, increased apoptosis and defective septation seen in BPD. More recently, Bland and colleagues reported an increase in elastin synthesis in mechanically ventilated newborn mice that was coupled with increased elastase activity and reduced lung abundance of proteins needed to regulate elastic fiber assembly, thus demonstrating a plausible explanation for altered lung elastin deposition, increased apoptosis, and defective septation, as observed in BPD [50].

\section{Infection}

Both cytomegalovirus (CMV) [51] and Ureaplasma spp. [52-54] infections are a signficant risk factor in the development of BPD in premature infants. Sawyer et al. [51] identified roentgenographic evidence that BPD occurred in 24 out of 32 postnatally CMV-infected premature infants compared to 12 out of 32 of the age-matched non-infected control group. Cassell et al. [52] demonstrated that premature infants $\leq 1,000 \mathrm{~g}$ with $U$. urealyticum infection of the lower respiratory tract were twice as likely to have BPD or to die than non-infected infants of sim- 
ilar birth weight or infants $>1,000 \mathrm{~g}$. Abele-Horn et al. [53] showed that $U$. urealyticum colonization was an important risk factor in the development of BPD even after treatment with surfactant. Benstein et al. [54] confirmed an association between $U$. urealyticum infection and BPD by histopathologic evidence of BPD on lung tissue from 7 infants at autopsy, with $U$. urealyticum identified by culture and in situ hybridization. They further described that 2 of the 7 infants with negative cultures for U. urealyticum were actually positive by in situ hybridization, and both had BPD at autopsy [54]. The other 5 infants with negative cultures for $U$. urealyticum were negative by in situ hybridization without evidence of BPD [54]. The role of Ureaplasma spp. treatment in BPD remains unclear. A Cochrane Review in 2003 identified that current evidence does not demonstrate a reduction in BPD or death when intubated preterm infants are treated with erythromycin prophylactically before $U$. urealyticum culture or polymerase chain reaction results are known or when $U$. urealyticum-colonized, intubated preterm infants are treated with erythromycin [55]. In this review, there were two small studies that differed in their design and were underpowered, so an actual benefit could easily be missed. More recently, azithromycin treatment resulted in improved survival, less emphysematous change, and reduced interleukin (IL)-6 levels in a rat model of BPD [56]. In a randomized, double-blind, placebo-controlled trial by Ballard et al. [57] where 220 infants with birth weight $\leq 1,250$ g were randomized to azithromycin or placebo within $72 \mathrm{~h}$ of beginning mechanical ventilation, azithromycin did not improve the clearance of Ureaplasma from tracheal aspirates, but there was less BPD in the treatment group (19/26; 73\%) compared to the placebo group (33/35; 94\%) when evaluating only infants that were Ureaplasma positive of their cohort.

Bhandari et al. [58] demonstrated that the presence of Mycoplasma in tracheal aspirates was associated with significant risk for developing severe BPD in neonates born at 26-32 weeks of gestation. In addition to postnatal infection, there has been speculation that antenatal chorioamnionitis may also be a contributing factor. In 1996, Watterberg et al. [59] established that intubated infants weighing $<2,000 \mathrm{~g}$ at birth who developed BPD had increased exposure to chorioamnionitis with resulting prenatal inflammation and evidence of increased lung inflammation from the 1st postnatal day with elevated IL$1 \beta$ levels in tracheal lavage aspirates. In an interesting study, Kramer et al. [60] demonstrated that severe lung inflammation occurs in preterm lambs that received mechanical ventilation with the introduction of low intra- tracheal endotoxin doses without high tidal volume ventilation. Young et al. [61] later identified that preterm infants exposed to chorioamnionitis have an increased incidence of early tracheal colonization, which may predispose them to develop BPD.

Kunzmann et al. [62] investigated the effects of chorioamnionitis-associated antenatal inflammation upon transforming growth factor (TGF)- $\beta_{1}$ and connective tissue growth factor (CTGF) in preterm lamb lungs. TGF- $\beta_{1}$ is a vital component of lung development, airway remodeling, lung fibrosis, and regulation of inflammation, all of which are involved in the development of BPD [62]. CTGF is a downstream mediator of some of the profibrotic effects of TGF- $\beta_{1}$, angiogenesis, and vascular remodeling [62]. Kunzmann et al. [62] demonstrated that intra-amniotic endotoxin increased lung TGF- $\beta_{1}$ mRNA and protein expression in the preterm lamb lungs. The elevated TGF- $\beta_{1}$ levels were associated with TGF- $\beta_{1}$-induced phosphorylation of Smad2, so antenatal inflammation-induced TGF- $\beta_{1}$ expression and Smad signaling in the fetal lamb lung may contribute to impaired lung alveolarization and reduced lung inflammation [62]. Decreased CTGF expression likely inhibits vascular development or remodeling and restricts lung fibrosis during remodeling [62]. Kunzmann et al. [62] concluded that these effects likely contribute to the impaired alveolar and pulmonary vascular development that is the hallmark of the 'new' form of BPD. The role of infection, alterations in immunity, and inflammation has been investigated extensively in the setting of BPD, and numerous reviews, including those of $\mathrm{Li}$ and Tullus [63], Jobe [64], and Speer [65], have been published on this subject.

Chorioamnionitis and postnatal infection may amplify the inflammatory response of the premature lung to mechanical ventilation [65]. Evidence exists that early systemic activation and transendothelial migration of neutrophils occur in RDS infants [66]. Elevated levels of cytokines, including IL- 6 and IL-8, precede the neutrophil influx [67] and may be the initiator of the inflammatory cascade that predisposes infants to the development of BPD [68].

\section{Pathophysiologic Factors in BPD}

\section{Adrenal Insufficiency}

Early adrenal insufficiency was associated with increased lung inflammation [69]. Cortisol levels correlated inversely with tracheal interleukins and proteins with lower cortisol values during the second half of the 1st 
Table 3. Genes associated with BPD

\begin{tabular}{lll}
\hline Marker & Polymorphism & Association with BPD \\
\hline ACE & deletion & BPD $\uparrow$ \\
GST & valine/isoleucine & BPD $\uparrow($ val) and (ile) \\
SP-A & SPA1-6A6 & BPD $\uparrow$ \\
SP-B & intron 4 deletion & BPD $\uparrow$ \\
TNF- $\alpha-238$ & adenosine/guanine & BPD $\downarrow$ \\
\hline
\end{tabular}

$\mathrm{ACE}=$ Angiotensin-converting enzyme; GST = glutathione $\mathrm{S}$ transferase.

week of life, correlating with longer duration of supplemental oxygen therapy and subsequent development of BPD at 28 postnatal days and at post-conceptional age of 36 weeks [69]. In another study involving preterm infants, basal cortisol levels during the 1st week were a weak predictor for BPD at 36 weeks PMA [70].

\section{Patent Ductus Arteriosus}

Patent ductus arteriosus (PDA) is associated with adverse respiratory outcome [69]. An association between PDA and BPD was reported, particularly in infants with extremely low birth weight [71]. Gonzalez et al. [72] demonstrated that the concurrence of PDA and infection increased the risk of BPD in preterm infants between 500 and 1,000 g. Rojas et al. [73] reported that low birth weight, PDA, and sepsis were significant risk factors for BPD in a cohort of 119 ventilator-supported preterm infants between 500 and $1,000 \mathrm{~g}$ who survived $>28$ days and required $<3$ days of fraction of inspired oxygen $>25 \%$ during the first 5 days of life. With simultaneous occurrence of sepsis and PDA, the odds ratio for BPD increased significantly in comparison with infants without these conditions [73]. Late episodes of PDA in association with nosocomial infection play a primary role in the pathogenesis of BPD in premature infants who initially have no or mild RDS [73]. The episodes of PDA were categorized as either early occurring during the 1st week of life or late after the 1st week [73].

\section{Genetic Susceptibility}

Recently, genetic susceptibility for BPD has emerged as a potential factor in the development of BPD. Twin studies have revealed that the BPD status of one twin, even after correcting for contributing factors, is a highly significant predictor of BPD in the second twin [74]. After controlling for covariates, genetic factors account for $53 \%$ of the variance in liability for BPD [74]. There have been several studies addressing genetic polymorphisms and their association with BPD [75-79]. Table 3 outlines these polymorphisms that have documented association with BPD. Genetic variations in other areas of development will likely be identified in the pathogenesis of BPD, including alveolar and vascular development, extracellular matrix synthesis, and NO synthesis, with others still yet to be defined as research continues.

Tumor necrosis factor (TNF)- $\alpha$ has been studied extensively and is a primary mediator of acute lung inflammation contributing to the pathophysiology of BPD [80]. TNF- $\alpha$ regulates TNF receptor (TNFR)-associated proteins in lung cells including TNFR-associated factor 1 (TRAF1) [80]. Immunohistochemical staining of human neonatal lung tissue demonstrated elevated levels of TRAF1 in lungs of infants dying of pneumonia or BPD in comparison with those dying of congenital malformation [80]. TNF- $\alpha$ is persistently elevated in ventilated preterm infants with RDS after 3 days of life [81]. Tullus et al. [82] described that TNF- $\alpha$, IL-1 $\beta$, IL-6, IL-1 receptor antagonist (IL-1Ra), and the neutrophil chemotactic factor, IL8 , were markedly elevated in tracheobronchial aspirate fluids from neonates with BPD. In an animal model of premature baboons, Coalson et al. [83] discovered significant elevations in TNF- $\alpha$, IL-6, and IL-8 levels, but not IL- $1 \beta$ and IL-10, in tracheal aspirate fluids at various times during the period of ventilatory support, with IL-8 levels also being elevated in necropsy lavages of animals with significant lung infection. Different polymorphisms of TNF- $\alpha$ exist with the adenine-containing alleles of TNF- $\alpha-308$ and lymphotoxin- $\alpha-250$ associated with increased levels of TNF- $\alpha$, whereas the adenine allele of TNF- $\alpha-238$ produces lower levels of TNF- $\alpha$ after stimulation [79]. The TNF- $\alpha-238$ genotypes were less likely to occur among infants with birth weights $\leq 1,250$ g who developed BPD compared to those infants who did not, and the number of adenine alleles of TNF- $\alpha-238$ correlated inversely with the severity of BPD, thus the adenine allele of TNF- $\alpha-238$ reduced the risk and severity of BPD [79]. Foundation for the term 'new' BPD is derived from proinflammatory genes including TNF- $\alpha$ [84]. The new BPD may begin in utero with progression postnatally, resulting in arrested lung development and alveolar hypoplasia [84]. Strassberg et al. [84] demonstrated that there was no association between BPD severity and the five TNF- $\alpha$ single nucleotide polymorphisms evaluated in their study. Haplotype-specific analysis revealed no significant association between BPD severity and any of the five marker common haplotypes with $\geq 10$ copies in their study population, with no significant association ob- 
served in any of the three single nucleotide polymorphism haplotypes at $-1,031,-863$, and -857 and in two at -308 and -238 [84].

\section{Surfactant Deficiency}

Surfactant abnormalities have been described in infants who develop BPD $[77,85,86]$ and in BPD animal models [87-89]. As discussed in the section on genetic susceptibility, polymorphism variations of both surfactant protein (SP)-A [77] and SP-B [78] are associated with the development of BPD. Sobel and Carroll [85] discovered that some infants of extremely low birth weight had respiratory deterioration with need for increased oxygen and ventilation requirements approximately 10 days after initial improvement with surfactant replacement therapy, so they reviewed antenatal, neonatal, and short-term outcome variables in infants with birth weights of 600 $1,000 \mathrm{~g}$ enrolled in a surfactant investigational treatment protocol. Survivors were grouped by number of doses given within the first $48 \mathrm{~h}$, with group 1 receiving one, two, or three doses and group 2 receiving four doses [85]. The need for four doses of surfactant was an early marker for post-surfactant respiratory deterioration, and BPD at 36 weeks post-conceptional age was more common in group 2 [85]. Merrill et al. [86] described that most premature infants requiring continued respiratory support after 7 days of age had transient periods of dysfunctional surfactant with a deficiency in SP-B and SP-C. In a double-blind, randomized, placebo-controlled study of surfactant therapy, circulating immune complexes between SP-A and anti-SP-A antibodies were measured in infants, and maximum immune complex values $2-4$ weeks after birth correlated significantly with the subsequent development of BPD independently of, and more strongly than, gestational age and birth weight [90]. Activated polymorphonuclear leukocytes are capable of impairing surfactant function in vitro and degrading the major apoprotein [91]. In 1984, Jefferies et al. [92] described the abnormal permeability to small solutes in the lungs of neonates with hyaline membrane disease with persistence of this abnormality in infants who subsequently develop BPD. This leakage of plasma proteins into the alveolar space inhibited surfactant function [93, 94]. However in 1998, Griese and Westerburg [95] demonstrated that the inhibition of surfactant function by proteins leaked into the airspaces did not play a major role during recovery from RDS, so they concluded that endogenous remodeling of surfactant might be of greater relevance. More recently, dexamethasone treatment not only significantly reduced inflammatory markers but also signifi- cantly increased the alveolar surfactant desaturated phosphatidylcholine pool in mechanically ventilated preterm infants with severe respiratory failure who were at high risk for developing BPD [96].

\section{Inflammation}

BPD develops in infants with enhanced inflammatory response in the setting of reduced or inhibited antiprotease activity. In a study by Merritt et al. [97], pulmonary effluent neutrophils, macrophages, and elastase activity were increased by day 3 of life in infants with RDS who eventually developed BPD, and elastase inhibitory capacity and $\alpha_{1}$-proteinase inhibitor activity were reduced in infants developing BPD. The proinflammatory cytokine IL-1 $\beta$ was significantly higher in the BAL fluid of infants who developed BPD [98]. An imbalance of IL- $1 \beta$ and its inhibitor, IL-1Ra, was described in prolonged inflammation, thus contributing to chronic lung injury and impaired healing in BPD [99]. IL-1 $\beta$ has a crucial role in inflammatory and immune responses by activating inflammatory cells, inducing the release of inflammatory mediators, and upregulating adhesion molecules on endothelial cells [100]. Injection of IL-1 $\beta$ into the pleural space of pigs resulted in a dose-dependent inflammatory response with formation of pleural exudate and leukocyte recruitment and was associated with the development of a hyperreactive phenomenon, which involved both the peripheral and large airways [101]. Bagchi et al. [102] reported that the pathway for inactivating or inhibiting the proinflammatory cytokine IL-6 is deficient in infants with BPD. Choi et al. [103] recently described that fetal pulmonary inflammation defined as IL- 6 levels $\geq 316 \mathrm{pg}$ / $\mathrm{ml}$ in tracheal aspirates together with PDA additively predicted the risk of BPD in a cohort of preterm infants born at $\leq 32$ weeks of gestation. Patterson et al. [104] discovered that infants with birth weights $\leq 1,250 \mathrm{~g}$ with $U$. urealyticum respiratory tract colonization had increased IL$1 \beta$ concentrations and IL-1 $\beta$ :IL- 6 ratios on day 1 and increased TNF- $\alpha$ :IL- 6 ratios on days 1 and 7-10 in tracheal aspirates. In their study, there was no clinical association between colonization and the development of BPD, but infants who developed BPD had significantly higher IL$1 \beta$ concentrations and ratios of IL-1 $\beta$ :IL- 6 in day 1 aspirates, thus suggesting that these may be early markers of lung inflammation in BPD [104].

Persistent inflammation is a major contributory factor in the development of BPD. In 1984, Ogden et al. [105] established that significant pulmonary polymorphonuclear leukocyte influxes using serial BAL were present at $96 \mathrm{~h}$ in patients with both RDS and BPD compared to 
control subjects, with normalization of polymorphonuclear counts by 1 week of life in RDS and significantly elevated counts continuing through 5 weeks of life in BPD. The BAL elastase $/ \alpha_{1}$-proteinase inhibitor ratios in RDS did not differ from those of normal control subjects; however, these ratios were significantly elevated from 1 through 4 weeks of life in BPD, placing these infants at risk for proteolytic lung damage [105]. Munshi et al. [67] demonstrated that elevations in IL-8 and IL- 6 levels precede the marked neutrophil influx seen in the tracheal aspirate of preterm infants who developed BPD, suggesting that these cytokines either initiate the acute inflammatory cascade in the lungs or are early markers of the inflammatory process that places preterm infants at high risk for BPD. The neutrophil chemoattractants IL-8, leukotriene $\mathrm{B}_{4}\left(\mathrm{LTB}_{4}\right)$, and platelet-activating factor (PAF) are expressed in the inflammatory process of BPD; consequently, Tan and Davidson [106] studied the potency difference of these chemoattractants in newborns and found a significant difference with IL- $8>\mathrm{LTB}_{4}>$ PAF. Migration to each of these mediators was almost completely due to chemotaxis as opposed to chemokinesis, and increased chemotaxis was due to the combination of IL- 8 and PAF or IL- 8 and LTB $_{4}$ without evidence of an increase in chemotaxis with the combination of PAF and $\mathrm{LTB}_{4}$ [106]. Su et al. [107] reported later that IL-8 in BAL was significantly increased in very low birth weight infants who developed BPD by 8 days of age compared to those infants who did not develop BPD.

In theory, blockade of acute inflammatory mediators may lead to reduced injury from hyperoxia in premature infants thus reducing the risk for the development of BPD. In a newborn rat model using rat neutrophil chemokines, Deng et al. [108] reported that antichemokine treatment prevented alveolar septal thickening and reduced chemokine immunolabeling in the setting of hyperoxia with 95\% oxygen administered. Yi et al. [109] demonstrated that exposure of the neonatal lung to moderate hyperoxia may enhance postnatal lung growth if postnatal pulmonary inflammation is suppressed. In the lung tissue of newborn rats exposed to $60 \%$ oxygen, a neutrophil chemokine that signals through the neutrophil CXC chemokine receptor-2 is increased [109]. Using a newborn rat model of BPD with the administration of $60 \%$ oxygen, Yi et al. [109] showed the complete inhibition of neutrophil influx using SB265610, a selective CXC chemokine receptor-2 antagonist, from birth to 14 days with attenuation of increased production of reactive oxygen species in newborn rat lung tissue after exposure to $60 \%$ oxygen for 4 days. Lung morphometric analysis revealed that $60 \%$ oxy- gen for 14 days, when accompanied by treatment with SB265610 to prevent neutrophil accumulation, increased alveolar formation over that seen in newborn rats exposed to room air [109]. The deficiency in anti-inflammatory cytokine expression may influence the development of BPD [110]. The production of the proinflammatory cytokines TNF- $\alpha$, IL- $1 \beta$, and IL- 8 is regulated in part by the anti-inflammatory cytokine IL-10 [110]. Jones et al. [110] demonstrated that IL-10 mRNA was undetectable in most of the cell samples from preterm infants and present in the majority of cell samples from term infants. A detailed review of the inflammatory response in BPD is well beyond the scope of this article; the current literature has already been reviewed by Bose et al. [111], Ryan et al. [112], and Kallapur and Jobe [113] on that topic.

\section{Pulmonary Arterial Hypertension}

Infants with BPD may develop pulmonary arterial hypertension (PAH) due to disruption of the pulmonary circulation structure and a rise in pulmonary vascular resistance due to alveolar injury and inadvertent periods of hypoxia. A very important factor in the development of PAH is the timing of the development of BPD, i.e. early/evolving BPD versus established BPD. In 1977, an echocardiographic study reported that increased pulmonary vascular resistance complicates acute, severe RDS in infants [114]. In 1991, Evans and Archer [115] demonstrated that higher estimated pulmonary artery pressure (PAP) was present in preterm infants with RDS compared to those infants without RDS over the first 5 days of life. These same authors further demonstrated that PAP fell over a 10-day period during the recovery phase of RDS [116]. Echocardiographic correlation of PAH was reported by Walther et al. [117] demonstrating that infants with RDS had near systemic PAP measurements at $12 \mathrm{~h}$ of life. Gill and Weindling [118] prospectively assessed 54 very low birth weight infants over 4 weeks by echocardiography, using time to peak velocity:right ventricular ejection time corrected for heart rate, with those infants who developed BPD having a diminished fall in PAP compared to the infants who did not.

By means of serial echocardiograms in 54 preterm infants who developed BPD and 44 healthy preterm infants, Subheder and Shaw [119] demonstrated that PAP remains elevated in infants with BPD during the 1st year of life with noninvasive assessments of PAP using Doppler-derived acceleration time to right ventricular ejection time ratio. It is not known whether these hemodynamics differences resulted from dysfunction or altered structure or growth of the pulmonary circulation. In 2007, Khemania 
et al. [120] studied 42 premature infants ( $<32$ weeks of gestation) with BPD and PAH, 2 or more months after birth (median age 4.8 months). The PAH was assessed by echocardiography with 13 patients also undergoing cardiac catheterization; a total of 18 of 42 patients had severe PAH with systemic or suprasystemic right ventricular pressure [120]. The 13 patients who underwent catheterization had a mean PAP of $43 \pm 8 \mathrm{~mm} \mathrm{Hg}$ and a pulmonary vascular resistance index of $9.9 \pm 2.8$ Wood units [120]. During the follow-up period, 16 of the 42 patients died with estimated survival rates being $64 \pm 8 \%$ at 6 months and $53 \pm 11 \% 2$ years after PAH diagnosis [120]. In multivariate analyses, severe $\mathrm{PAH}$ and small birth weight for gestational age were associated with worse survival rates [120]. There was an improvement in PAH in 24 of the 26 survivors with median follow-up being 9.8 months [120].

Using cardiac catheterization, Mourani et al. [121] demonstrated that hyperoxia and inhaled NO caused marked pulmonary vasodilatation in older patients with BPD (median age 5 months, range $0.33-27$ months), thus suggesting that the heightened pulmonary vascular tone is a contributing factor in the pulmonary vascular disease of BPD. More recently, they assessed the clinical utility of Doppler echocardiography in predicting the presence and severity of PAH in BPD patients who subsequently underwent cardiac catheterization [122]. The accuracy of echocardiography in diagnosing $\mathrm{PAH}$ with estimated systolic PAP was compared to the detection of PAH with the standard method of cardiac catheterization [122]. Systolic PAP could be estimated in $61 \%$ of studies, but poor correlation was noted between echocardiography and cardiac catheterization measures of systolic PAP in the infants studied [122]. Compared to cardiac catheterization, echocardiographic estimates of systolic PAP di- agnosed correctly the presence or absence of PAH in 79\% of the studies in which systolic PAP was estimated, but determined the severity of PAH correctly in only $47 \%$ of studies (severe PAH was defined as a pulmonary/systemic pressure ratio $\geq 0.67$ ) [122]. Interestingly, a total of 7 of 12 children without estimated systolic PAP demonstrated PAH during cardiac catheterization [122].

\section{Conclusions}

Our understanding of BPD is an evolving process that begins in utero and progresses postnatally with continuation of pulmonary impairment into later childhood and on into adulthood. A complicating factor in the evaluation of outcome in patients with BPD is the changing treatment and management of these patients as neonatal care improves with advancements in technology and a better understanding of the disease. Current therapy during the neonatal period includes surfactant replacement, supportive ventilation strategies with lower mean airway pressures and permissive hypercapnia, inhaled and systemic corticosteroid therapy, bronchodilators, diuretic therapy, vitamin A therapy, and optimal nutrition. A particular factor in BPD where our knowledge is lacking more than others is $\mathrm{PAH}$, since our most commonly used diagnostic modality, echocardiography, does not accurately estimate systolic PAP consistently. Thus, a very important factor in the management of BPD is the accurate diagnosis of $\mathrm{PAH}$, which is more reliable by cardiac catheterization, for maximal therapy. Continued research is essential to further define the disease process of BPD and to evaluate pulmonary outcome to optimize medical management and treatment of these patients.

\section{References}

1 Northway WH Jr, Rosan RC, Porter DY: Pulmonary disease following respirator therapy of hyaline-membrane disease. Bronchopulmonary dysplasia. N Engl J Med 1967;276: 357-368.

$\checkmark 2$ Pusey VA, Macpherson RI, Chernick V: Pulmonary fibroplasia following prolonged artificial ventilation of newborn infants. Can Med Assoc J 1969;100:451-457.

-3 Kraybill EN, Runyan DK, Bose CL, Khan JH: Risk factors for chronic lung disease in infants with birth weights of 751 to 1000 grams. J Pediatr 1989;115:115-120.
-4 Sinkin RA, Cox C, Phelps DL: Predicting risk for bronchopulmonary dysplasia: selection criteria for clinical trials. Pediatrics 1990;86:728-736.

5 Shennan AT, Dunn MS, Ohlsson A, et al: Abnormal pulmonary outcomes in premature infants: prediction from oxygen requirement in the neonatal period. Pediatrics 1988 ; 82:527-532.

6 Marshall DD, Kotelchuck M, Young TE, Bose CL, Kruyer L, O'Shea TM: Risk factors for chronic lung disease in the surfactant era: a North Carolina population-based study of very low birth weight infants. North Caro- lina Neonatologists Association. Pediatrics 1999; 104:1345-1350.

7 Jobe AH, Bancalari E: Bronchopulmonary dysplasia. Am J Respir Crit Care Med 2001; 163:1723-1729.

8 Ehrenkranz RA, Walsh MC, Vohr BR, Jobe AH, Wright LL, Fanaroff AA, Wrage LA, Poole K, National Institutes of Child Health and Human Development Neonatal Research Network: Validation of the National Institutes of Health consensus definition of bronchopulmonary dysplasia. Pediatrics 2005;116:1353-1360. 
-9 Cherukupalli K, Larson JE, Rotschild A, Thurlbeck WM: Biochemical, clinical, and morphologic studies on lungs of infants with bronchopulmonary dysplasia. Pediatr Pulmonol 1996;22:215-229.

10 Husain AN, Siddiqui NH, Stocker JT: Pathology of arrested acinar development in postsurfactant bronchopulmonary dysplasia. Hum Pathol 1998;29:710-717.

11 Coalson JJ: Pathology of new bronchopulmonary dysplasia. Semin Neonatol 2003;8: 73-81.

12 Langston C, Thurlbeck WM: Lung growth and development in late gestation and early postnatal life. Perspect Pediatr Pathol 1982; 7:203-235.

13 Langston C, Kida K, Reed M, Thurlbeck WM: Human lung growth in late gestation and in the neonate. Am Rev Respir Dis 1984; 129:607-613.

14 Burri PH: Structural aspects of prenatal and postnatal development and growth of the lung; in McDonald JA (ed): Structural Aspects of Prenatal and Postnatal Development and Growth of the Lung. New York, Dekker, 1997, pp 1-35.

15 Jakkula M, Le Cras TD, Gebb S, Hirth KP, Tuder RM, Voelkel NF, Abman SH: Inhibition of angiogenesis decreases alveolarization in the developing rat lung. Am J Physiol Lung Cell Mol Physiol 2000;279:L600L607.

16 Abman SH: Bronchopulmonary dysplasia: 'a vascular hypothesis'. Am J Respir Crit Care Med 2001;164:1755-1756.

17 Hislop AA: Airway and blood vessel interaction during lung development. J Anat 2002; 201:325-334.

18 Hall SM, Hislop AA, Haworth SG: Origin, differentiation, and maturation of human pulmonary veins. Am J Respir Cell Mol Biol 2002;26:333-340.

19 Maniscalco WM, Watkins RH, Pryhuber GS, Bhatt A, Shea C, Huyck H: Angiogenic factors and alveolar vasculature: development and alterations by injury in very premature baboons. Am J Physiol Lung Cell Mol Physiol 2002;282:L811-L823.

20 Bhatt AJ, Pryhuber GS, Huyck H, Watkins RH, Metlay LA, Maniscalco WM: Disrupted pulmonary vasculature and decreased vascular endothelial growth factor, Flt-1, and TIE-2 in human infants dying with bronchopulmonary dysplasia. Am J Respir Crit Care Med 2001;164:1971-1980.

-21 Lassus P, Turanlahti M, Heikkilä P, Andersson LC, Nupponen I, Sarnesto A, Andersson S: Pulmonary vascular endothelial growth factor and Flt-1 in fetuses, in acute and chronic lung disease, and in persistent pulmonary hypertension of the newborn. Am J Respir Crit Care Med 2001;164:19811987.

-22 Thébaud B, Ladha F, Michelakis ED, Sawicka M, Thurston G, Eaton F, Hashimoto K, Harry G, Haromy A, Korbutt G, Archer SL: Vascular endothelial growth factor gene therapy increases survival, promotes lung angiogen- esis, and prevents alveolar damage in hyperoxia-induced lung injury: evidence that angiogenesis participates in alveolarization. Circulation 2005;112:2477-2486.

-23 Bhandari V, Choo-Wing R, Lee CG, Yusuf K, Nedrelow JH, Ambalavanan N, Malkus H, Homer RJ, Elias JA: Developmental regulation of NO-mediated VEGF-induced effects in the lung. Am J Respir Cell Mol Biol 2008; 39:420-430.

24 Escobedo MB, Hilliard JL, Smith F, Meredith K, Walsh W, Johnson D, Coalson JJ, Kuehl TJ, Null DM Jr, Robotham JL: A baboon model of bronchopulmonary dysplasia. I. Clinical features. Exp Mol Pathol 1982; 37:323-334.

25 Welty SE, Smith CV: Rationale for antioxidant therapy in premature infants to prevent bronchopulmonary dysplasia. Nutr Rev 2001;59:10-17.

26 Welty SE: Antioxidants and oxidations in bronchopulmonary dysplasia: there are no easy answers. J Pediatr 2003;143:697-698.

27 Asikainen TM, White CW: Pulmonary antioxidant defenses in the preterm newborn with respiratory distress and bronchopulmonary dysplasia in evolution: implications for antioxidant therapy. Antioxid Redox Signal 2004;6:155-167.

28 Asikainen TM, Raivio KO, Saksela M, Kinnula VL: Expression and developmental profile of antioxidant enzymes in human lung and liver. Am J Respir Cell Mol Biol 1998;19: 942-949.

-29 Fu RH, Chiu TH, Chiang MC, Lien R, Chou YH, Chiang CC, Cho YH, Yang PH: Lower erythrocyte glutathione peroxidase activity in bronchopulmonary dysplasia in the first week of neonatal life. Neonatology 2008;93: 269-275.

30 Jain A, Mehta T, Auld PA, Rodrigues J, Ward RF, Schwartz MK, Mårtensson J: Glutathione metabolism in newborns: evidence for glutathione deficiency in plasma, bronchoalveolar lavage fluid, and lymphocytes in prematures. Pediatr Pulmonol 1995;20:160166.

- 31 Moison RM, Haasnoot AA, van ZoerenGrobben D, Berger HM: Red blood cell glutathione and plasma sulfhydryls in chronic lung disease of the newborn. Acta Paediatr 1997;86:1363-1369.

32 Ahola T, Lapatto R, Raivio KO, Selander B, Stigson L, Jonsson B, Jonsbo F, Esberg G, Stövring S, Kjartansson S, Stiris T, Lossius K, Virkola K, Fellman V: N-acetylcysteine does not prevent bronchopulmonary dysplasia in immature infants: a randomized controlled trial. J Pediatr 2003; 143:713-719.

33 Shenai JP, Chytil F, Jhaveri A, Stahlman MT: Plasma vitamin A and retinol-binding protein in premature and term neonates. J Pediatr 1981;99:302-305.

34 Veness-Meehan KA, Pierce RA, Moats-Staats BM, Stiles AD: Retinoic acid attenuates $\mathrm{O}_{2}$-induced inhibition of lung septation. Am J Physiol Lung Cell Mol Physiol 2002;283: L971-L980.
35 Bland RD, Albertine KH, Pierce RA, Starcher BC, Carlton DP: Impaired alveolar development and abnormal lung elastin in preterm lambs with chronic lung injury: potential benefits of retinol treatment. Biol Neonate 2003;84:101-102.

36 Darlow BA, Graham PJ: Vitamin A supplementation for preventing morbidity and mortality in very low birth weight infants (review). Cochrane Database Syst Rev 2002; 4:CD000501.

37 Tyson JE, Wright LL, Oh W, Kennedy KA, Mele L, Ehrenkranz RA, Stoll BJ, Lemons JA, Stevenson DK, Bauer CR, Korones SB, Fanaroff AA: Vitamin A supplementation for extremely-low-birth-weight infants. National Institute of Child Health and Human Development Neonatal Research Network. N Engl J Med 1999;340:1962-1968.

- 38 Watts JL, Milner R, Zipursky A, Paes B, Ling E, Gill G, Fletcher B, Rand C: Failure of supplementation with vitamin $\mathrm{E}$ to prevent bronchopulmonary dysplasia in infants less than 1,500 g birth weight. Eur Respir J 1991; 4:188-190.

39 Davis JM, Parad RB, Michele T, Allred E, Price A, Rosenfeld W, North American Recombinant Human CuZnSOD Study Group: Pulmonary outcome at 1 year corrected age in premature infants treated at birth with recombinant human $\mathrm{CuZn}$ superoxide dismutase. Pediatrics 2003;111:469-476

40 Frank L: Antioxidants, nutrition, and bronchopulmonary dysplasia. Clin Perinatol 1992;19:541-562.

41 Varsila E, Pesonen E, Andersson S: Early protein oxidation in the neonatal lung is related to development of chronic lung disease. Acta Paediatr 1995;84:1296-1299.

42 Varsila E, Hallman M, Andersson S: Freeradical-induced lipid peroxidation during the early neonatal period. Acta Paediatr 1994;83:692-695.

43 Collard KJ, Godeck S, Holley JE, Quinn MW: Pulmonary antioxidant concentrations and oxidative damage in ventilated premature babies. Arch Dis Child Fetal Neonatal Ed 2004;89:F412-F416.

44 Taghizadeh A, Reynolds EO: Pathogenesis of bronchopulmonary dysplasia following hyaline membrane disease. Am J Pathol 1976;82: 241-264.

45 Stahlman M, Hedvall G, Lindstrom D, Snell $\mathrm{J}$ : Role of hyaline membrane disease in production of later childhood lung abnormalities. Pediatrics 1982;69:572-576.

46 Albertine KH, Jones GP, Starcher BC, Bohnsack JF, Davis PL, Cho SC, Carlton DP, Bland RD: Chronic lung injury in preterm lambs. Disordered respiratory tract development. Am J Respir Crit Care Med 1999;159:945958.

-47 Garland JS, Buck RK, Allred EN, Leviton A: Hypocarbia before surfactant therapy appears to increase bronchopulmonary dysplasia risk in infants with respiratory distress syndrome. Arch Pediatr Adolesc Med 1995; 149:617-622. 
48 Björklund LJ, Vilstrup CT, Larsson A, Svenningsen NW, Werner O: Changes in lung volume and static expiratory pressure-volume diagram after surfactant rescue treatment of neonates with established respiratory distress syndrome. Am J Respir Crit Care Med 1996;154:918-923.

-49 Bland RD, Mokres LM, Ertsey R, Jacobson BE, Jiang S, Rabinovitch M, Xu L, Shinwell ES, Zhang F, Beasley MA: Mechanical ventilation with $40 \%$ oxygen reduces pulmonary expression of genes that regulate lung development and impairs alveolar septation in newborn mice. Am J Physiol Lung Cell Mol Physiol 2007;293:L1099-L1110.

-50 Bland RD, Ertsey R, Mokres LM, Xu L, Jacobson BE, Jiang S, Alvira CM, Rabinovitch M, Shinwell ES, Dixit A: Mechanical ventilation uncouples synthesis and assembly of elastin and increases apoptosis in lungs of newborn mice. Prelude to defective alveolar septation during lung development? Am J Physiol Lung Cell Mol Physiol 2008;294:L3L14.

-51 Sawyer MH, Edwards DK, Spector SA: Cytomegalovirus infection and bronchopulmonary dysplasia in premature infants. Am J Dis Child 1987;141:303-305.

- 52 Cassell GH, Waites KB, Crouse DT, Rudd PT, Canupp KC, Stagno S, Cutter GR: Association of Ureaplasma urealyticum infection of the lower respiratory tract with chronic lung disease and death in very-low-birth-weight infants. Lancet 1988;ii:240-245.

-53 Abele-Horn M, Genzel-Boroviczény O, Uhlig T, Zimmermann A, Peters J, Scholz M: Ureaplasma urealyticum colonization and bronchopulmonary dysplasia: a comparative prospective multicentre study. Eur J Pediatr 1998;157:1004-1011.

- 54 Benstein BD, Crouse DT, Shanklin DR, Ourth DD: Ureaplasma in lung. 2. Association with bronchopulmonary dysplasia in premature newborns. Exp Mol Pathol 2003; 75:171-177.

55 Mabanta CG, Pryhuber GS, Weinberg GA, Phelps DL: Erythromycin for the prevention of chronic lung disease in intubated preterm infants at risk for, or colonized or infected with Ureaplasma urealyticum. Cochrane Database Syst Rev 2003;4:CD003744.

- 56 Ballard HO, Bernard P, Qualls J, Everson W, Shook LA: Azithromycin protects against hyperoxic lung injury in neonatal rats. J Investig Med 2007;55:299-305.

57 Ballard HO, Bernard PA, Hayes D, Anstead MI, Desai NS, Smart EJ, Kryscio R, Shook LA: Use of azithromycin for the prevention of bronchopulmonary dysplasia: a randomized, double-blind, placebo-controlled trial. Am J Respir Crit Care Med 2009; 179: A4126.

58 Bhandari V, Hussain N, Rosenkrantz T, Kresch M: Respiratory tract colonization with mycoplasma species increases the severity of bronchopulmonary dysplasia. J Perinat Med 1998;26:37-42.
59 Watterberg KL, Demers LM, Scott SM, Murphy S: Chorioamnionitis and early lung inflammation in infants in whom bronchopulmonary dysplasia develops. Pediatrics 1996; 97:210-215.

60 Kramer BW, Ikegami M, Jobe AH: Intratracheal endotoxin causes systemic inflammation in ventilated preterm lambs. Am J Respir Crit Care Med 2002;165:463-469.

61 Young KC, Del Moral T, Claure N, Vanbuskirk S, Bancalari E: The association between early tracheal colonization and bronchopulmonary dysplasia. J Perinatol 2005;25:403407.

62 Kunzmann S, Speer CP, Jobe AH, Kramer BW: Antenatal inflammation induced TGF$\beta 1$ but suppressed CTGF in preterm lungs. Am J Physiol Lung Cell Mol Physiol 2007; 292:L223-L231.

63 Li YH, Tullus K: Microbial infection and inflammation in the development of chronic lung disease of prematurity. Microbes Infect 2002;4:723-732.

64 Jobe AH: Antenatal factors and the development of bronchopulmonary dysplasia. Semin Neonatol 2003;8:9-17.

65 Speer CP: Inflammation and bronchopulmonary dysplasia. Semin Neonatol 2003;8: 29-38.

66 Sarafidis K, Drossou-Agakidou V, Kanakoudi-Tsakalidou F, Taparkou A, Tsakalidis C, Tsandali C, Kremenopoulos G: Evidence of early systemic activation and transendothelial migration of neutrophils in neonates with severe respiratory distress syndrome. Pediatr Pulmonol 2001;31:214-219.

67 Munshi UK, Niu JO, Siddiq MM, Parton LA: Elevation of interleukin-8 and interleukin- 6 precedes the influx of neutrophils in tracheal aspirates from preterm infants who develop bronchopulmonary dysplasia. Pediatr Pulmonol 1997;24:331-336.

68 Kotecha S, Wilson L, Wangoo A, Silverman $M$, Shaw RJ: Increase in interleukin (IL)-1 beta and IL-6 in bronchoalveolar lavage fluid obtained from infants with chronic lung disease of prematurity. Pediatr Res 1996;40: 250-256.

69 Watterberg KL, Scott SM, Backstrom C, Gifford KL, Cook KL: Links between early adrenal function and respiratory outcome in preterm infants: airway inflammation and patent ductus arteriosus. Pediatrics 2000; 105:320-324.

70 Banks BA, Stouffer N, Cnaan A, Ning Y, Merrill JD, Ballard RA, Ballard PL, North American Thyrotropin-Releasing Hormone Trial Collaborators: Association of plasma cortisol and chronic lung disease in preterm infants. Pediatrics 2001;107:494-498.

71 Brown ER: Increased risk of bronchopulmonary dysplasia in infants with patent ductus arteriosus. J Pediatr 1979;95:865-866.
72 Gonzalez A, Sosenko IR, Chandar J, Hummler H, Claure N, Bancalari E: Influence of infection on patent ductus arteriosus and chronic lung disease in premature infants weighing 1000 grams or less. J Pediatr 1996; 128:470-478.

-73 Rojas MA, Gonzalez A, Bancalari E, Claure N, Poole C, Silva-Neto G: Changing trends in the epidemiology and pathogenesis of neonatal chronic lung disease. J Pediatr 1995; 126:605-610.

74 Bhandari V, Gruen JR: The genetics of bronchopulmonary dysplasia. Semin Perinatol 2006;30:185-191.

75 Kazzi SN, Quasney MW: Deletion allele of angiotensin-converting enzyme is associated with increased risk and severity of bronchopulmonary dysplasia. J Pediatr 2005;147: 818-822.

-76 Manar MH, Brown MR, Gauthier TW, Brown LA: Association of glutathione-Stransferase-P1 (GST-P1) polymorphisms with bronchopulmonary dysplasia. J Perinatol 2004;24:30-35.

77 Weber B, Borkhardt A, Stoll-Becker S, Reiss I, Gortner L: Polymorphisms of surfactant protein A genes and the risk of bronchopulmonary dysplasia in preterm infants. Turk J Pediatr 2000;42:181-185.

78 Rova M, Haataja R, Marttila R, Ollikainen V, Tammela O, Hallman M: Data mining and multiparameter analysis of lung surfactant protein genes in bronchopulmonary dysplasia. Hum Mol Genet 2004;13:10951104.

79 Kazzi SN, Kim UO, Quasney MW, Buhimschi I: Polymorphism of tumor necrosis factor-alpha and risk and severity of bronchopulmonary dysplasia among very low birth weight infants. Pediatrics 2004;114:e243e248.

80 Pryhuber GS, Huyck HL, Staversky RJ, Finkelstein JN, O'Reilly MA: Tumor necrosis factor-alpha-induced lung cell expression of antiapoptotic genes TRAF1 and cIAP2. Am J Respir Cell Mol Biol 2000;22:150-156.

-81 Murch SH, MacDonald TT, Wood CB, Costeloe KL: Tumour necrosis factor in the bronchoalveolar secretions of infants with the respiratory distress syndrome and the effect of dexamethasone treatment. Thorax 1992;47:44-47.

82 Tullus K, Noack GW, Burman LG, Nilsson R, Wretlind B, Brauner A: Elevated cytokine levels in tracheobronchial aspirate fluids from ventilator treated neonates with bronchopulmonary dysplasia. Eur J Pediatr 1996; 155:112-116.

83 Coalson JJ, Winter VT, Siler-Khodr T, Yoder BA: Neonatal chronic lung disease in extremely immature baboons. Am J Respir Crit Care Med 1999;160:1333-1346.

-84 Strassberg SS, Cristea IA, Qian D, Parton LA: Single nucleotide polymorphisms of tumor necrosis factor-alpha and the susceptibility to bronchopulmonary dysplasia. Pediatr Pulmonol 2007;42:29-36. 
85 Sobel DB, Carroll A: Postsurfactant slump: early prediction of neonatal chronic lung disease? J Perinatol 1994;14:268-274.

-86 Merrill JD, Ballard RA, Cnaan A, Hibbs AM, Godinez RI, Godinez MH, Truog WE, Ballard PL: Dysfunction of pulmonary surfactant in chronically ventilated premature in fants. Pediatr Res 2004;56:918-926.

- 87 ter Horst SA, Fijlstra M, Sengupta S, Walther FJ, Wagenaar GT: Spatial and temporal expression of surfactant proteins in hyperoxiainduced neonatal rat lung injury. BMC Pulm Med 2006;6:8.

-88 Coalson JJ, King RJ, Yang F, Winter V, Whitsett JA, Delemos RA, Seidner SR: SP-A deficiency in primate model of bronchopulmonary dysplasia with infection. In situ mRNA and immunostains. Am J Respir Crit Care Med 1995;151:854-866.

-89 King RJ, Coalson JJ, deLemos RA, Gerstmann DR, Seidner SR: Surfactant protein-A deficiency in a primate model of bronchopulmonary dysplasia. Am J Respir Crit Care Med 1995;151:1989-1997.

90 Strayer DS, Merritt TA, Hallman M: Levels of SP-A-anti-SP-A immune complexes in neonatal respiratory distress syndrome correlate with subsequent development of bronchopulmonary dysplasia. Acta Paediatr 1995;84:128-131.

-91 Ryan SF, Ghassibi Y, Liau DF: Effects of activated polymorphonuclear leukocytes upon pulmonary surfactant in vitro. Am J Respir Cell Mol Biol 1991;4:33-41.

92 Jefferies AL, Coates G, O’Brodovich H: Pulmonary epithelial permeability in hyalinemembrane disease. N Engl J Med 1984;311: $1075-1080$.

93 Ikegami M, Jacobs H, Jobe A: Surfactant function in respiratory distress syndrome. J Pediatr 1983;102:443-447.

-94 Seeger W, Grube C, Günther A, Schmidt R: Surfactant inhibition by plasma proteins: differential sensitivity of various surfactant preparations. Eur Respir J 1993;6:971-977.

-95 Griese M, Westerburg B: Surfactant function in neonates with respiratory distress syndrome. Respiration 1998;65:136-142.

$\$ 6$ Cogo PE, Simonato M, Mariatoffolo G, Stefanutti G, Chierici M, Cobelli C, Ori C, Carnielli VP: Dexamethasone therapy in preterm infants developing bronchopulmonary dysplasia: effect on pulmonary surfactant disaturated-phosphatidylcholine kinetics. Pediatr Res 2008;63:433-437.

-97 Merritt TA, Cochrane CG, Holcomb K, Bohl B, Hallman M, Strayer D, Edwards DK 3rd, Gluck L: Elastase and alpha 1-proteinase inhibitor activity in tracheal aspirates during respiratory distress syndrome. Role of inflammation in the pathogenesis of bronchopulmonary dysplasia. J Clin Invest 1983;72: 656-666.

98 Rozycki HJ: Bronchoalveolar interleukin-1 beta in infants on day 1 of life. South Med J 1994;87:991-996.
$\$ 99$ Rindfleisch MS, Hasday JD, Taciak V, Broderick K, Viscardi RM: Potential role of interleukin-1 in the development of bronchopulmonary dysplasia. J Interferon Cytokine Res 1996;16:365-373.

100 Dinarell CA, Wolff SM: The role of interleukin-1 in disease. N Engl J Med 1993;328: 106-113.

101 Hernandez A, Omini C, Daffonchio L: Interleukin-1 beta: a possible mediator of lung inflammation and airway hyperreactivity. Pharmacol Res 1991;24:385-393.

102 Bagchi A, Viscardi RM, Taciak V, Ensor JE, McCrea KA, Hasday JD: Increased activity of interleukin- 6 but not tumor necrosis factor-alpha in lung lavage of premature infants is associated with the development of bronchopulmonary dysplasia. Pediatr Res 1994;36:244-252.

103 Choi CW, Kim BI, Kim HS, Park JD, Choi $\mathrm{JH}$, Son DW: Increase of interleukin-6 in tracheal aspirate at birth: a predictor of subsequent bronchopulmonary dysplasia in preterm infants. Acta Paediatr 2006;95:3843.

104 Patterson AM, Taciak V, Lovchik J, Fox RE, Campbell AB, Viscardi RM: Ureaplasma urealyticum respiratory tract colonization is associated with an increase in interleukin 1-beta and tumor necrosis factor alpha relative to interleukin 6 in tracheal aspirates of preterm infants. Pediatr Infect Dis J 1998; 17:321-328

105 Ogden BE, Murphy SA, Saunders GC, Pathak D, Johnson JD: Neonatal lung neutrophils and elastase/proteinase inhibitor imbalance. Am Rev Respir Dis 1984;130: 817-821.

106 Tan ND, Davidson D: Comparative differences and combined effects of interleukin8, leukotriene B4, and platelet-activating factor on neutrophil chemotaxis of the newborn. Pediatr Res 1995;38:11-16.

107 Su BH, Chiu HY, Lin TW, Lin HC: Interleukin-8 in bronchoalveolar lavage fluid of premature infants at risk of chronic lung disease. J Formos Med Assoc 2005; 104: 244-248.

108 Deng H, Mason SN, Auten RL Jr: Lung inflammation in hyperoxia can be prevented by antichemokine treatment in newborn rats. Am J Respir Crit Care Med 2000;162: 2316-2323.

109 Yi M, Jankov RP, Belcastro R, Humes D, Copland I, Shek S, Sweezey NB, Post M, Albertine KH, Auten RL, Tanswell AK: Opposing effects of $60 \%$ oxygen and neutrophilinflux on alveologenesis in the neonatal rat. Am J Respir Crit Care Med 2004;170: 1188-1196.

110 Jones CA, Cayabyab RG, Kwong KY, Stotts C, Wong B, Hamdan H, Minoo P, deLemos RA: Undetectable interleukin (IL)-10 and persistent IL-8 expression early in hyaline membrane disease: a possible developmental basis for the predisposition to chronic lung inflammation in preterm newborns. Pediatr Res 1996;39:966-975.
111 Bose CL, Dammann CE, Laughon MM: Bronchopulmonary dysplasia and inflammatory biomarkers in the premature neonate. Arch Dis Child Fetal Neonatal Ed 2008;93:F455-F461.

112 Ryan RM, Ahmed Q, Lakshminrusimha S: Inflammatory mediators in the immunobiology of bronchopulmonary dysplasia. Clin Rev Allergy Immunol 2008;34:174-190.

113 Kallapur SG, Jobe AH: Contribution of inflammation to lung injury and development. Arch Dis Child Fetal Neonatal Ed 2006;91:F132-F135.

114 Halliday H, Hirschfeld S, Riggs T, Liebman J, Fanaroff A, Bormuth C: Respiratory distress syndrome: echocardiographic assessment of cardiovascular function and pulmonary vascular resistance. Pediatrics 1977;60:444-449.

115 Evans NJ, Archer LN: Doppler assessment of pulmonary artery pressure and extrapulmonary shunting in the acute phase of hyaline membrane disease. Arch Dis Child 1991;66:6-11.

116 Evans NJ, Archer LN: Doppler assessment of pulmonary artery pressure during recovery from hyaline membrane disease. Arch Dis Child 1991;66:802-804.

117 Walther FJ, Benders MJ, Leighton JO: Persistent pulmonary hypertension in premature neonates with severe respiratory distress syndrome. Pediatrics 1992;90: 899-904.

118 Gill AB, Weindling AM: Pulmonary artery pressure changes in the very low birthweight infant developing chronic lung disease. Arch Dis Child 1993;68:303-307.

119 Subhedar NV, Shaw NJ: Changes in pulmonary arterial pressure in preterm infants with chronic lung disease. Arch Dis Child Fetal Neonatal Ed 2000;82:F243-F247.

120 Khemani E, McElhinney DB, Rhein L, Andrade O, Lacro RV, Thomas KC, Mullen MP: Pulmonary artery hypertension in formerly premature infants with bronchopulmonary dysplasia: clinical features and outcomes in the surfactant era. Pediatrics 2007;120:1260-1269.

>121 Mourani PM, Ivy DD, Gao D, Abman SH: Pulmonary vascular effects of inhaled nitric oxide and oxygen tension in bronchopulmonary dysplasia. Am J Respir Crit Care Med 2004;170:1006-1013.

122 Mourani PM, Sontag MK, Younoszai A, Ivy DD, Abman SH: Clinical utility of echocardiography for the diagnosis and management of pulmonary vascular disease in young children with chronic lung disease. Pediatrics 2008;121:317-325. 